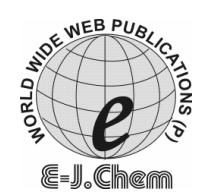

http://www.e-journals.net
ISSN: 0973-4945; CODEN ECJHAO

E-Journal of Chemistry 2008, 5(S2), 1144-1148

\title{
Anti-Inflammatory Activity of Hydroxytriazenes and their Vanadium Complexes
}

\author{
KALPANA SINGH, PEEYUSH PATEL and A.K. GOSWAMI* \\ Co-ordination Chemistry Laboratory, \\ M.L. Sukhadia University, Udaipur 313001, India. \\ akumargoswami@rediffmail.com
}

Received 27 March 2008; Accepted 5 June 2008

\begin{abstract}
The anti-inflammatory activity of hydroxytriazenes as well as their vanadium complexes has been studied using carrageenan induced hind paw oedema method in albino rats (Wister strain). Hydroxytriazenes viz., 3-hydroxy1,3-diphenyltriazene (HT-1), 3-hydroxy-3-phenyl-1-(4-sulfonamido)phenyl triazene (HT-2), 3-hydroxy-3-p-chlorophenyl-1-(4-sulfonamido) phenyltriazene (HT-3), 3-hydroxy-3-m-chlorophenyl-1-(4-sulfonamido)phenyltriazene (HT-4) and their respective vanadium complexes $\mathrm{C}-1, \mathrm{C}-2, \mathrm{C}-3$ and $\mathrm{C}-4$ have been synthesized using standard methods, purified, characterized and used for studying their anti-inflammatory activities. The hind paw oedema was produced by subplanter injection of carrageenan and the paw volume was measured plethysmographically after $0.5,1,2,3$ and $5 \mathrm{~h}$. The animals were given HT-1, HT-2, HT-3 and HT-4 and also vanadium complexes C-1, C-2, C-3 and C-4 dissolved in DMSO (at dose $5 \mathrm{mg} / \mathrm{Kg}$ body weight). Diclofenac sodium (5 $\mathrm{mg} / \mathrm{kg}$ ) was used as a standard drug. The standard drug shows maximum inibition up to $1 \mathrm{~h}$ as $81.73 \%$ which goes on increasing up to $3 \mathrm{~h}(88.94 \%)$ but further reduces to $74.93 \%$ at the end of $5 \mathrm{~h}$. The test compounds i.e. both ligands as well as their metal complexes show maximum percent inhibition only up to 1h. after which the efficacy reduces. Thus it can be said that both ligands as well as their vanadium complexes show very significant anti-inflammatory activity up to $1 \mathrm{~h}$ which is comparable to standard drug.
\end{abstract}

Keywords: Anti-inflammatory activity, Hydroxytriazenes, Vanadium complexes.

\section{Introduction}

Hydroxytriazenes are a useful group of chelating agents. Their analytical utility in the spectrophotometric determination of both transition and non-transition metal ions is well established, as revealed by appearance of eight reviews ${ }^{1-8}$ during last few years. Apart from the reference of Gublar ${ }^{9}$, some attempts have been made to study biological activity of 
hydroxytriazenes in our laboratory ${ }^{10}$. In the present investigation four hydroxytriazenes as well as their respective vanadium complexes have been synthesized and screened for their anti-inflammatory activity on the basis of PASS (Prediction of biological activity spectra for substances) which indicated good theoretical possibility of anti-inflammatory activity in these compounds.

\section{Experimental}

\section{Synthesis of hydroxytriazenes}

All the four hydroxytriazenes were synthesized as per standard method ${ }^{11}$. The general method is described below. Except for the difference in substituent, synthesis incorporated the same experimental conditions. The synthesis was done in three steps.

1. Preparation of arylhydroxylamine: In the preparation of aryl hydroxylamine, 0.2 moles of nitro aryl compound, $30 \mathrm{~g}$ of $\mathrm{NH}_{4} \mathrm{Cl}$ and $250 \mathrm{~mL}$ of water were mixed and stirred mechanically at $40^{\circ} \mathrm{C}$ and then $40 \mathrm{~g}$ of $\mathrm{Zn}$ dust was added in the small lots such that the temperature of the reaction remained between $45-60^{\circ} \mathrm{C}$. The reaction mixture was filtered, washed with ice cold water and the solution obtained was kept in refrigerator at about $0^{\circ} \mathrm{C}$ which was used for coupling.

2. Preparation of aryldiazonium salts: Aryl amine $(0.2$ moles $)$ was dissolved in mixture containing $50 \mathrm{~mL}$ of $\mathrm{HCl}$ and $50 \mathrm{~mL}$ of water. In other beaker 0.2 moles sodium nitrite was dissolved in minimum quantity of water. The temperature of the aryl amine hydrochloride solution was maintained between $0-5^{\circ} \mathrm{C}$. To this solution, sodium nitrite solution was added drop by drop with stirring. The diazotized product so obtained was directly used for coupling.

3. Coupling: The temperature of aryl hydroxylamine prepared in step- 1 and diazotised product obtained from step- 2 was maintained between $0-5^{\circ} \mathrm{C}$. Step- 2 solution was added drop-by-drop to solution obtained in step 1 and $\mathrm{pH}$ of solution was maintained between 5 and 6 by adding sodium acetate buffer. The resultant product was filtered, washed with cold water and dried. The crude compounds were purified and recrystallized. The purity of each hydroxytriazene was checked by I.R. studies and physical characteristics such as M.P. crystal shape etc. Their compositions were verified by elemental analysis. All these data have been given in Table 1 .

4. Preparation of vanadium complexes : On the basis of solution and molar composition studies it was found that vanadium forms 1:1 complex with hydroxytriazenes in the $\mathrm{pH}$ range 5.8 - 8.5. Thus all the complexes were prepared using appropriate ratios and reaction conditions. The complexes were duly characterized by $\mathrm{CHN}$ analysis and IR spectral studies before screening for anti-inflammatory activity. The physical characteristics have been incorporated in table-1 along with $\mathrm{CHN}$ data.

\section{Animals}

Experiments were performed on albino rats of either sex (Wister strain) weighing (150-175 g). They were given standard laboratory diet and water ad Libitum.

\section{Anti-inflammatory activity}

Carrageenan induced paw oedema: Anti-inflammatory activity was determined by paw oedema method in rats described ${ }^{12}$ by Winter et al., (1962). The rats were divided into ten group ( $\mathrm{n}=6)$. Group I was served as control (saline). Group II was given diclofenac sodium orally $(5 \mathrm{mg} / \mathrm{kg})$ as a standard drug. Groups III-VI were administered hydroxytriazene compounds (HT-1, HT-2, HT-3, HT-4) and groups VII-X were administered their respective vanadium complexes (C-1, C-2, C-3, C-4), $5 \mathrm{mg} / \mathrm{kg}$ orally. 
Table 1. Physical characteristics data of the test compounds.

\begin{tabular}{|c|c|c|c|c|c|c|c|}
\hline \multirow{2}{*}{ Compound } & \multirow{2}{*}{ Name } & \multicolumn{4}{|c|}{ Elemental analysis } & \multirow{2}{*}{$\underset{{ }^{\circ} \mathrm{C}}{\text { M.P. }}$} & \multirow{2}{*}{$\begin{array}{l}\text { Characteristic } \\
\text { I.R. bands, } \mathrm{cm}^{-1} \\
\end{array}$} \\
\hline & & & $\% \mathrm{C}$ & $\% \mathrm{H}$ & $\% \mathrm{~N}$ & & \\
\hline \multirow[t]{2}{*}{ HT-1 } & \multirow{2}{*}{$\begin{array}{l}\text { 3-hydroxy-1,3- } \\
\text { diphenyltriazene }\end{array}$} & Th & 67.60 & 5.16 & 19.72 & 119 & $\vee \mathrm{OH}=3480$ \\
\hline & & Ex & 67.60 & 5.18 & 18.70 & & $v \mathrm{NH}-3190$ \\
\hline \multirow[t]{2}{*}{ HT-2 } & \multirow{2}{*}{$\begin{array}{l}\text { 3-hydroxy-3-phenyl-1-(4- } \\
\text { sulfonamido)phenyltriazene }\end{array}$} & Th & 49.28 & 4.13 & 19.17 & 170 & $v \mathrm{OH}=3415(\mathrm{~s})$ \\
\hline & & Ex & 47.29 & 5.34 & 19.63 & & $v \mathrm{NH}=3250(\mathrm{~b})$ \\
\hline \multirow[t]{2}{*}{ HT-3 } & \multirow{2}{*}{$\begin{array}{l}\text { 3-hydroxy-3-m- } \\
\text { chlorophenyl-1-(4- } \\
\text { sulfonamido)phenyl-triazene }\end{array}$} & Th & 44.10 & 3.36 & 17.15 & 150 & $\vee \mathrm{OH}=3580$ \\
\hline & & Ex & 44.98 & 3.30 & 16.30 & & $v \mathrm{NH}=3230$ \\
\hline \multirow[t]{2}{*}{ HT-4 } & \multirow{2}{*}{$\begin{array}{l}\text { 3-hydroxy-3-p-chlorophenyl- } \\
\text { 1-(4-sulfonamido) } \\
\text { phenyltriazene }\end{array}$} & Th. & 44.10 & 3.36 & 17.15 & 161 & $\vee \mathrm{OH}=3588$ \\
\hline & & Ex & 42.88 & 3.00 & 16.36 & & v NH - 3290 \\
\hline \multirow[t]{2}{*}{$\mathrm{C}-1$} & \multirow[t]{2}{*}{$\mathrm{VO}\left(\mathrm{C}_{12} \mathrm{H}_{11} \mathrm{~N}_{3} \mathrm{O}\right)_{2}$} & Th & 58.66 & 4.10 & 17.10 & $* *$ & $*$ \\
\hline & & Ex & 58.62 & 4.09 & 17.00 & & \\
\hline \multirow[t]{2}{*}{$\mathrm{C}-2$} & \multirow[t]{2}{*}{$\mathrm{VO}\left(\mathrm{C}_{12} \mathrm{H}_{11} \mathrm{~N}_{4} \mathrm{O}_{3} \mathrm{~S}\right)_{2}$} & Th & 44.28 & 3.68 & 17.20 & $* *$ & $*$ \\
\hline & & Ex & 43.68 & 3.14 & 16.23 & & \\
\hline \multirow[t]{2}{*}{ C-3 } & \multirow[t]{2}{*}{$\mathrm{VO}\left(\mathrm{C}_{12} \mathrm{H}_{11} \mathrm{~N}_{4} \mathrm{O}_{3} \mathrm{SCl}\right)_{2}$} & Th & 40.00 & 3.05 & 15.55 & $* *$ & $*$ \\
\hline & & Ex & 40.11 & 3.82 & 14.56 & & \\
\hline \multirow[t]{2}{*}{ C-4 } & \multirow[t]{2}{*}{$\mathrm{VO}\left(\mathrm{C}_{12} \mathrm{H}_{11} \mathrm{~N}_{4} \mathrm{O}_{3} \mathrm{SCl}\right)_{2}$} & Th. & 40.00 & 3.05 & 15.55 & $* *$ & $*$ \\
\hline & & Ex & 39.00 & 14.06 & 14.98 & & \\
\hline
\end{tabular}

*The characteristic peaks in complex disappeared at the desired positions $\overline{\text { showing complex }}$ formation. ** No sharp melting points.

The paw volume was measured by plethysmographic method at $(0.5,1,2,3,5 \mathrm{~h})$, after the sub planter injection of $0.1 \mathrm{~mL}$ of $1 \%$ freshly prepared suspension of carrageenan (Sigma Chemical Co.). Drug pretreatment was given $1 \mathrm{~h}$ before the injection of carrageenan. Mean increase in paw volume was measured, expressed as mean + SEM and \% inhibition was calculated. The values have been incorporated in Table 2 .

\section{Results and Discussion}

Perusal of Table 2 shows that all the four hydroxytriazenes and their vanadium complexes efficiently act to inhibit inflammation. The results are comparable to the standard drug diclofenac sodium. The distinct feature of diclofenac sodium is that effect from 0.5 to $5 \mathrm{~h}$ has regular trend and value decreases to $74.93 \%$ at $5 \mathrm{~h}$, ranging from 75 to $89 \%$. Thus average efficiency of the standard drug is more than $75 \%$. The test compounds i.e. hydroxytriazenes in general show maximum inhibition percentage at about 1h (except HT-2 which shows maximum value at $0.5 \mathrm{~h}$ ) and $\mathrm{C}-4$ which also show maximum value at $0.5 \mathrm{~h}$ ). With time after $1 \mathrm{~h}$ it goes on reducing and minimum at about $5 \mathrm{~h}$.

Basically inflammation is a protective response to cell injuries in animals. It is manifested in the form of common clinical signs such as erythema, oedema, hyperalgesia, pain and loss of function at macroscopic level. To study the anti-inflammatory activity of any compound the suppression of these signs is observed in laboratory animals. This includes 
using three models viz. acute, sub-acute and chronic. In the present study carageenan induced acute inflammation model has been used for studies. The results have been compared with standard drug diclofenac sodium which is categorized as a NSAID (Non-steroid antiinflammatory drug) this category of drug acts at the periphery and not at CNS. Acting at the site of tissue injury these drugs block the synthesis of ecosanoids, finally blocking the cycloxygenase (COX) pathway.

Table 2. Effect of hydroxytriazenes and their vanadium complexes on carrageenan induced rat paw edema.

\begin{tabular}{|c|c|c|c|c|c|c|}
\hline \multirow{2}{*}{$\begin{array}{l}\text { Groups } \\
(n=6)\end{array}$} & \multirow{2}{*}{$\begin{array}{c}\text { Dose } \\
\text { Unit/Kg }\end{array}$} & \multicolumn{5}{|c|}{ Edema volume after } \\
\hline & & $0.5 \mathrm{~h}$ & $1 \mathrm{~h}$ & $2 \mathrm{~h}$ & $3 \mathrm{~h}$ & $5 \mathrm{~h}$ \\
\hline $\begin{array}{l}\text { Control } \\
\text { (Saline) }\end{array}$ & $5 \mathrm{~mL}$ & $2.85 \pm 0.24$ & $6.36 \pm 0.96$ & $7.30 \pm 0.72$ & $8.00 \pm 0.84$ & $7.36 \pm 0.89$ \\
\hline $\begin{array}{c}\text { Control } \\
\text { DMSO } \\
\text { (Vehicle) }\end{array}$ & $5 \mathrm{~mL}$ & $\begin{array}{l}2.83 \pm 0.13 \\
\quad(0.70)\end{array}$ & $\begin{array}{c}6.34 \pm 0.41 \\
(0.15)\end{array}$ & $\begin{array}{c}7.36 \pm 0.35 \\
(0.82)\end{array}$ & $\begin{array}{c}8.18 \pm 0.39 \\
(2.25)\end{array}$ & $\begin{array}{c}7.38 \pm 0.58 \\
(0.27)\end{array}$ \\
\hline $\begin{array}{l}\text { Diclofenac } \\
\text { Sodium }\end{array}$ & $5 \mathrm{mg}$ & $\begin{array}{c}0.61 \pm 0.20^{* *} \\
(78.44)\end{array}$ & $\begin{array}{c}1.16 \pm 0.37 * * \\
(81.73)\end{array}$ & $\begin{array}{c}1.30 \pm 0.40^{* * *} \\
(82.34)\end{array}$ & $\begin{array}{c}0.90 \pm 0.40^{* * *} \\
(88.94)\end{array}$ & $\begin{array}{c}1.85 \pm 0.46^{* * *} \\
(74.93)\end{array}$ \\
\hline HT-1 & $5 \mathrm{mg}$ & $\begin{array}{c}1.28 \pm 0.29 * * \\
(54.77)\end{array}$ & $\begin{array}{c}3.12 \pm 0.38^{* *} \\
(50.87)\end{array}$ & $\begin{array}{c}6.26 \pm 0.67^{\mathrm{NS}} \\
(14.95)\end{array}$ & $\begin{array}{c}7.23 \pm 0.49^{\mathrm{NS}} \\
(11.61)\end{array}$ & $\begin{array}{c}7.26 \pm 0.62^{\mathrm{NS}} \\
(0.02)\end{array}$ \\
\hline HT-2 & $5 \mathrm{mg}$ & $\begin{array}{c}0.25 \pm 0.14^{* *} \\
(91.17)\end{array}$ & $\begin{array}{c}0.51 \pm 0.34 * * \\
(91.95)\end{array}$ & $\begin{array}{c}1.91 \pm 0.34^{* *} \\
(74.04)\end{array}$ & $\begin{array}{c}2.71 \pm 0.45^{* *} \\
(66.87)\end{array}$ & $\begin{array}{c}4.50 \pm 0.48^{* *} \\
(39.03)\end{array}$ \\
\hline HT-3 & $5 \mathrm{mg}$ & $\begin{array}{c}1.60 \pm 0.23^{* *} \\
(43.46)\end{array}$ & $\begin{array}{c}2.38 \pm 0.39 * * \\
\quad(62.51)\end{array}$ & $\begin{array}{c}2.98 \pm 0.50 * * \\
(59.51)\end{array}$ & $\begin{array}{c}3.60 \pm 0.43^{* * *} \\
(55.99)\end{array}$ & $\begin{array}{c}3.83 \pm 0.60 \\
(38.34)\end{array}$ \\
\hline HT-4 & $5 \mathrm{mg}$ & $\begin{array}{c}2.21 \pm 0.20^{* *} \\
(21.91)\end{array}$ & $\begin{array}{c}2.71 \pm 0.42^{* *} \\
(57.32)\end{array}$ & $\begin{array}{c}3.33 \pm 0.34 * * \\
(54.75)\end{array}$ & $\begin{array}{c}4.48 \pm 0.49^{* * *} \\
(45.23)\end{array}$ & $\begin{array}{c}4.55 \pm 0.51^{* * *} \\
(38.34)\end{array}$ \\
\hline $\mathrm{C}-1$ & $5 \mathrm{mg}$ & $\begin{array}{c}1.21 \pm 0.42 \\
(57.03)\end{array}$ & $\begin{array}{c}2.52 \pm 0.49 \\
(60.22)\end{array}$ & $\begin{array}{c}4.44 \pm 0.59 \\
(39.67)\end{array}$ & $\begin{array}{c}6.03 \pm 0.05 \\
(26.24)\end{array}$ & $\begin{array}{c}6.23 \pm 1.16 \\
(15.58)\end{array}$ \\
\hline $\mathrm{C}-2$ & $5 \mathrm{mg}$ & $\begin{array}{c}0.73 \pm 0.28 \\
(74.09)\end{array}$ & $\begin{array}{c}1.35 \pm 0.38 \\
(78.74)\end{array}$ & $\begin{array}{c}2.00 \pm 0.46 \\
(72.82)\end{array}$ & $\begin{array}{c}2.50 \pm 0.42 \\
(69.43)\end{array}$ & $\begin{array}{c}3.60 \pm 0.45 \\
(51.21)\end{array}$ \\
\hline $\mathrm{C}-3$ & $5 \mathrm{mg}$ & $\begin{array}{c}1.19 \pm 0.15 \\
(57.84)\end{array}$ & $\begin{array}{c}2.19 \pm 0.44 \\
(65.46)\end{array}$ & $\begin{array}{c}2.66 \pm 0.52 \\
(63.86)\end{array}$ & $\begin{array}{c}3.16 \pm 0.57 \\
(61.30)\end{array}$ & $\begin{array}{c}3.22 \pm 0.16 \\
(56.37)\end{array}$ \\
\hline C-4 & $5 \mathrm{mg}$ & $\begin{array}{c}0.41 \pm 0.23 \\
(85.30) \\
\end{array}$ & $\begin{array}{c}1.35 \pm 0.44 \\
(78.74) \\
\end{array}$ & $\begin{array}{c}1.76 \pm 0.34 \\
(76.01) \\
\end{array}$ & $\begin{array}{c}2.20 \pm 0.46 \\
(73.10) \\
\end{array}$ & $\begin{array}{c}2.41 \pm 0.48 \\
(67.26) \\
\end{array}$ \\
\hline
\end{tabular}

Each value is the mean \pm SEM of 6 rats. Figure in parentheses indicates the \% anti-inflammatory activity. ${ }^{*} p<0.05 ; * *<0.001$ compared to control. NS : Statistically not significant

Both ligands as well as vanadium complexes are showing moderate to very good antiinflammatory activity up to $1 \mathrm{~h}$, which goes on reducing with the time. The probable mechanism of action of carageenan induced edema is bi-phasic; the first phase is attributed to release of histamine -HT, kinins in the first hour while the second phase is attributed to 
the release of prostaglandin like substance in $2-3 \mathrm{~h}$. The activity of hydroxytriazenes is structure dependent and is excellent in inhibiting carageenan induced edema.

DMSO has no anti-inflammatory activity. The parent compound HT-1 has little activity. The substitution in benzene ring at 1 position by sulphonomide group enhances antiinflammatory activity significantly. It can be observed that HT-2 has better activity compared to standard drug at $0.5 \mathrm{~h}$. Further complex C-4 also has activity greater than the standard drug at $0.5 \mathrm{~h}$. Although structure activity relationship with such a small number of observations can not be established one thing is clear that both ligands as well as their vanadium complexes can be potential anti-inflammatory drugs if explored further.

\section{Acknowledgement}

Authors are thankful to Council of Scientific and Industrial Research, New Delhi, India for providing JRF to one of the author (P. Patel)

\section{References}

1. Purohit D N, Talanta, 1967, 14, 353.

2. Purohit D N and Golwalkar A M, Acta Ciecia Indica., 1985, 11, 1-9.

3. Purohit D N, Nizamuddin and Golwalkar A M, Revs Anal Chem., 1985, 8, 13-123.

4. Purohit D N, Tyagi M P and Banu S, Proc Soc Quim., (Peru), 1985, 51, 117.

5. Purohit D N, Tyagi M P and Banu S, Oriental J Chem., 1986, 2, 64.

6. Goswami A K, Khan S, Dashora R and Purohit D N, Revs Anal Chem., 2004, 25, 1-74.

7. Goswami A K, Chauhan R S and Singh K A, Main Group Metal Chem.. 2005, 28(3), 119-148.

8. Goswami A K, Chauhan R S and Dalawat D S, Revs Anal Chem., 2005, 24, 75-102.

9. Gubler K, Ger Offen (CA 1970, 73, 13181 C) 1970, 2003333-54.

10. Goswami A K and Purohit D N, Analytical Sciences 2001, 17, 789 - 791.

11. Sogani N C and Bhatacharya S C, J Indian Chem Soc., 1957, 36, 563-566.

12. Winter C A, Risley E A and Noss G W, Proc Soc Exp Biol Med., 1962, 111, 544-547. 


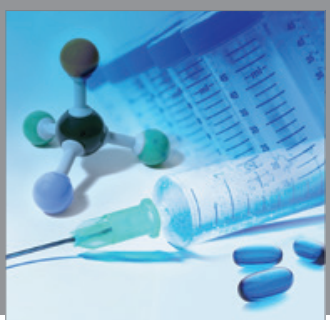

International Journal of

Medicinal Chemistry

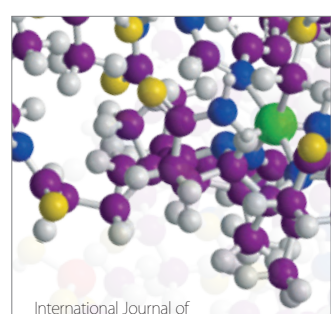

Carbohydrate Chemistry

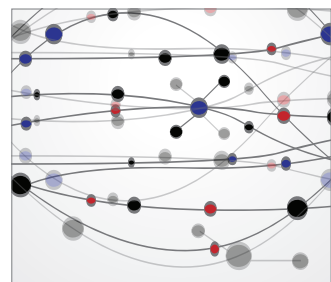

The Scientific World Journal
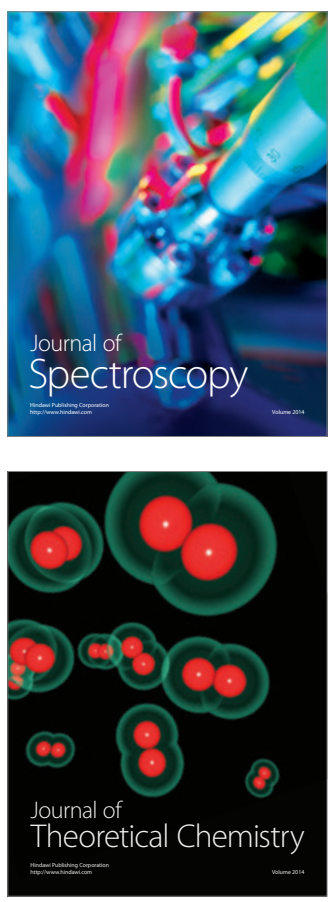
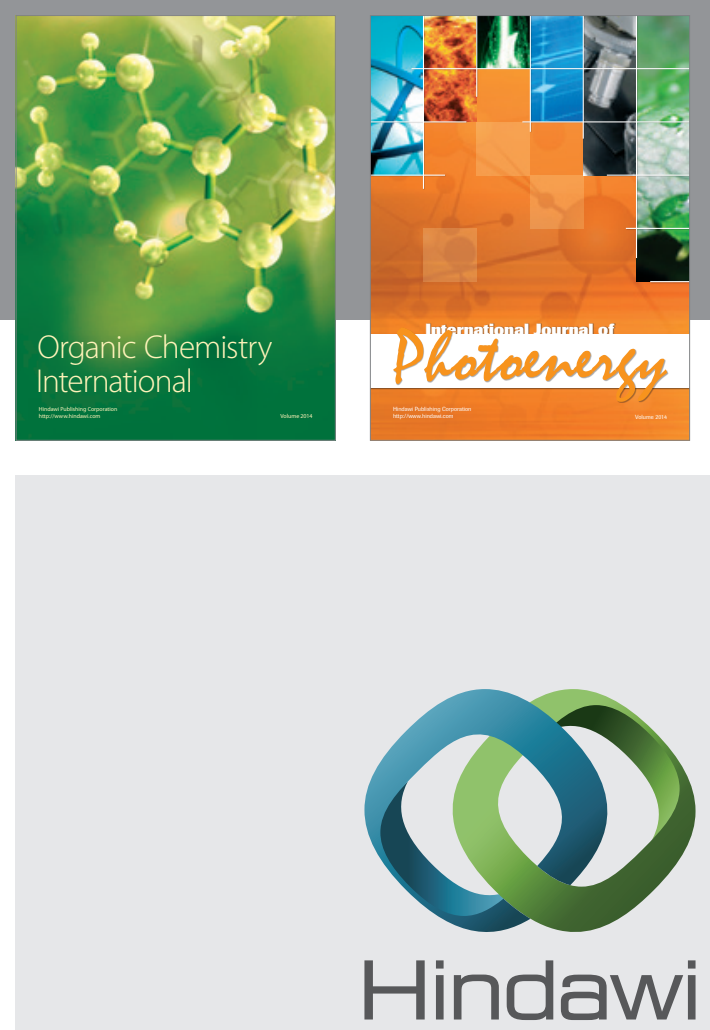

Submit your manuscripts at

http://www.hindawi.com
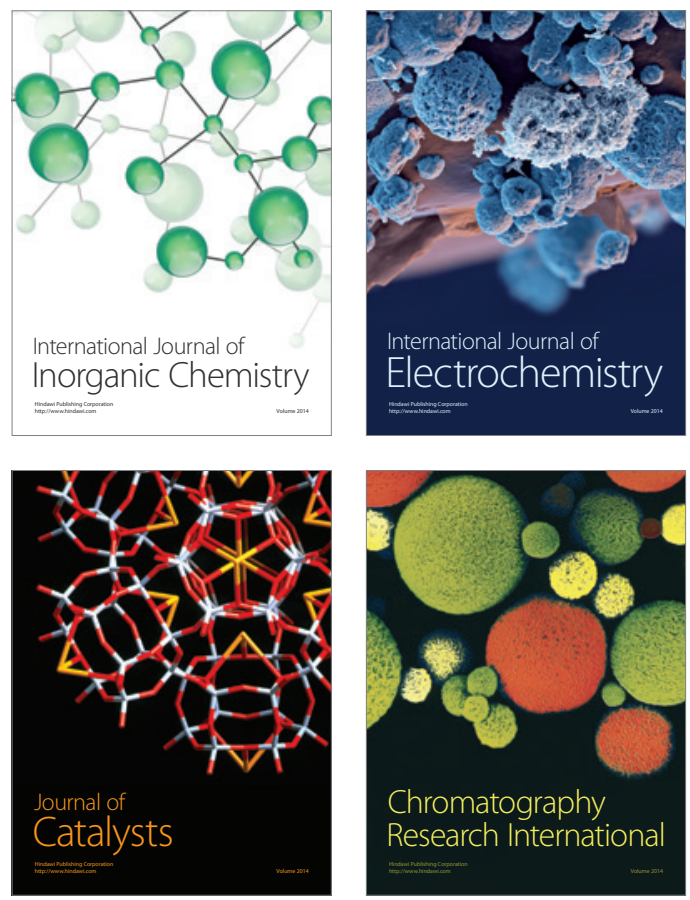
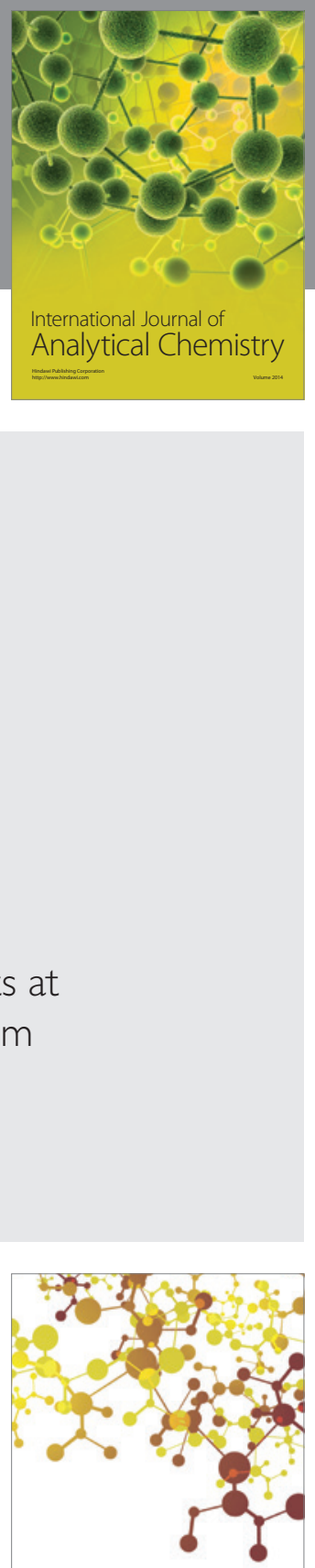

Journal of

Applied Chemistry
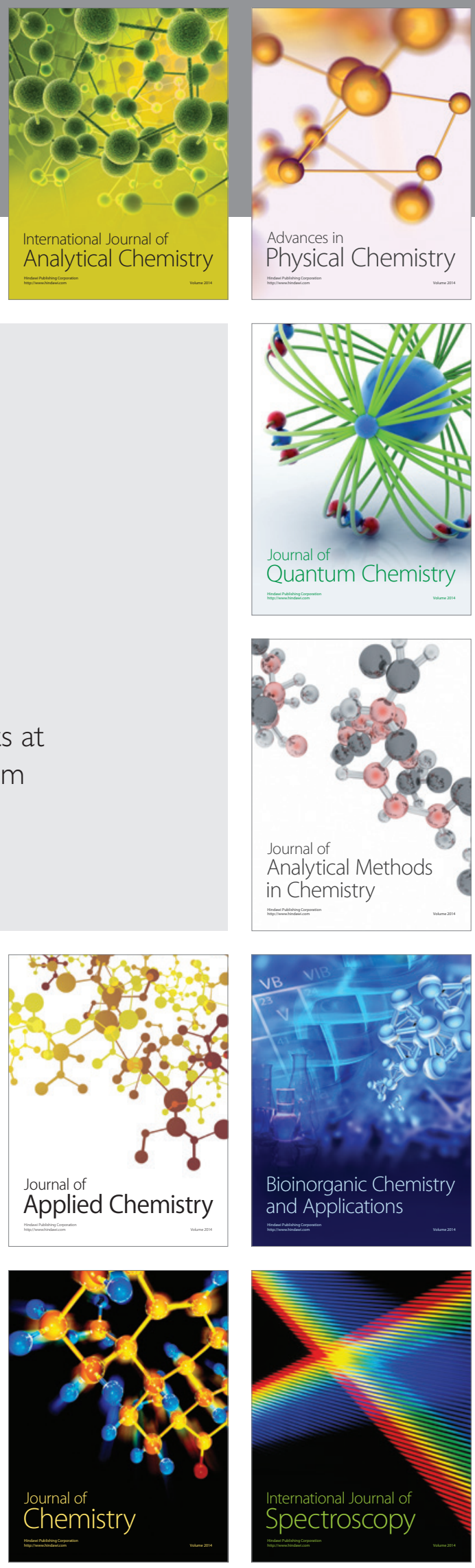